\title{
Mezhep Faktörünün Muhaddisler Üzerindeki Etkisi (Memlükler Dönemi-Hanefî-Şafiî Bağlamında)
}

\author{
Arş. Gör. Dr. Nagihan Emiroğlu ${ }^{1 *}$ \\ Arş. Gör. Dr. Fatmanur Alibekiroğlu Eren ${ }^{2}$
}

Gelis tarihi: 13.10 .2019

Kabul tarihi: 01.11.2019

\section{Atıf bilgisi:}

IBAD Sosyal Bilimler Dergisi

Sayı: $5 \quad$ Sayfa: $444-457$

Yıl: 2019 Dönem: Güz

This article was checked by Turnitin. Similarity Index 7\%

${ }^{1}$ Çukurova Üniversitesi İlahiyat Fakültesi, Türkiye,nyanar@cu.edu.tr ORCID ID 0000-0002-9998-3486

2 Çukurova Üniversitesi İlahiyat Fakültesi, Türkiye, falibekiroglu@,cu.edu.tr, ORCID ID 0000- 0001-9629-5736

\begin{abstract}
ÖZ
Yaklaşık üç asır hüküm süren (VII-X) ve bir Türk devleti olan Memlükler, her ilim dalında olduğu gibi hadis alanında da gerek âlimler ve gerekse ortaya konan eserler bakımından oldukça zengin bir dönemdir. Bu dönemde ilk defa dört mezhep için ayrı kadılkudatlar atanarak mezheplere karşı daha dengeli bir politika takip edilmiştir. Her ne kadar Şafii eğitim kurumları ve muhaddisler sayıca daha fazla olsa da bu dönemde bir mezhep olarak Hanefílik ve Hanefî muhaddisler de oldukça velut ve etkin konumda olmuşlardır. İbn Balabân (ö. 739/1339), İbnü't-Türkmânî (ö. 750/1350), Moğultay b. Kılıç (ö. 762/1361), Abdullah b. Yusuf ez-Zeylâî (ö. 762/1361), Aynî (ö. 855/1451), İbn Kutluboğa (ö. 879/1474) gibi Hanefî muhaddisler eserleri ve fikirleriyle İslâm düşüncesinin şekillenmesine önemli katkı sağlamışlardır. Hanefî muhaddisler, bazen mezhep taraftarlığı yaparak Şafii muhaddislerle rekabet halinde olurken bazen de birbirleriyle olumlu düzeyde bir ilişki içerisinde olmuşlardır. Bu makale söz konusu dönemde yetişen Hanefî muhaddisleri ve bu muhaddislerin Şafii meslektaşlarıyla olan olumlu-olumsuz münasebetlerini örneklerle göstermeyi amaçlamaktadır.
\end{abstract}

Anahtar Kelimeler: Türk (Bahrî) Memlükler, hadis, muhaddis, Hanefî, Şâfiî

\footnotetext{
* Sorumlu yazar
} 
First received: 13.10 .2019

Accepted: 01.11.2019

\section{Citation:}

IBAD Journal of Social Sciences

Issue: 5 Pages: 444-457

Year: 2019

Session: Fall

This article was checked by Turnitin. Similarity Index $7 \%$

1 Cukurova University, Turkey, nyanar@,cu.edu.tr

ORCID ID 0000-0002-9998-3486

2 Cukurova University, Turkey, falibekiroglu@cu.edu.tr

ORCID ID 0000- 0001-9629-5736

\footnotetext{
* Corresponding Author
}

\begin{abstract}
Mamluk State is a Turkish State and Mamalukes reigned three centruies (VII-X) Period of Mamalukes is rich term as in the field of all science branches also in the field of hadith with regard to scholars and written works. In this time, Qadilqudats (chief qadi) were assigned for the first time for other three Sects as well as Shafii Sect. Thus, balanced policy was provided for four sects. Even though Shafii Educational Institution and Shafii Muhaddiths were too much, Hanafism and Hanafi Muhaddiths were quite effective position. İbn Balabân (d. 739/1339), İbnü'tTürkmânî (d. 750/1350), Moğultay b. Kılıç (d. 762/1361), Abdullah b. Yusuf ezZeylâî (d. 762/1361), Aynî (d. 855/1451) ve İbn Kutluboğa (d. 879/1474) of Hanafi Muhaddiths made a significant contribution for the shaping of Islamic thought with their works and opinions. This study aims to demonstrate positive-negative relationships between Hanafi and Shafii Muhaddiths.
\end{abstract}

Keywords: Turkish (Bahri) Mamluks, hadith, muhaddith, Hanafi, Shafii 


\section{GíRIS}

Herhangi bir mezhebin teşekkülü ve geliştirdiği doktrinin benimsenip yayılma süreci, uzun yıllar gerektiren ve tek bir sebebe bağlanamayacak kadar girift, sosyal, kültürel ve dinî bir olgudur. $\mathrm{Bu}$ bağlamda Ebû Hanife ve talebelerinin temsil ettiği Irâk fikıh ekolünün, Hanefî mezhebî olarak isimlendirilip kemikleşmesi, yüzyıllarla ifade edilen bir süreci kapsamaktadır. Hulefâ-yi Râşîîn ve Emeviler döneminde halife tarafindan tayin edilen ve gönderildikleri yerlerde bağımsız olarak faaliyet gösteren müçtehid kadıların, İslâm coğrafyasının genişlemesi ile her bölgeye gönderilme imkânı azalmıştır. Bu durumla birlikte yargıda düzen ve istikrarın sağlanma ihtiyacı, Abbâsî halifesi Hârûnürreşîd'in Ebû Yusuf'u kadılkûdat tayin etmesini beraberinde getirmiştir. Bu tayinden sonra Irak fıkıh ekolüne (Hanefî mezhebi) mensup kadıların tayin edilmesi, Hanefî̀ mezhebinin bölgede tanınıp yayılmasına hizmet etmiştir. Daha çok Irak ve doğusunda yayılan Hanefî mezhebinin, Abbasîler döneminde tayin edilen Hanefî kadılar sayesinde giderek Mısır ve çevresinde de tanınması sağlansa da, mezhebin Suriye ve Mısır'da yayılışı, bölgede Selçuklu/Türk hâkimiyetinin başladığı V. Yüzyılın ikinci yarısında olmuştur. Eyyûbîler döneminde ise sünnîliği temsil etmede revaçta olan Eş'arîlik ve Şâfiîlik yönetim tarafindan desteklenmiş ve Şâfiî mezhebi mensubları, diğer mezhep mensuplarından oldukça imtiyazlı bir konuma gelmişlerdir. Böylece Suriye ve Mısır'ın Eyyûbî hâkimiyetine girmesiyle kadılkudâtların Şâfii mezhebi mensuplarından atanması ve Şafiiler'in özel himaye görmesi sebebiyle, gerek eğitim kurumları ve gerekse nüfus itibariyle Hanefîlik, ikinci sırada yer almışır (Bardakoğlu, 1997, s. 1-9). Bu çalışma Memlükler döneminde Hanefî ve Şâfii mezheblerinin konumunu, bu dönemde yetişen bazı muhaddisleri ve onların Şafii meslektaşlarıyla olan ilişkilerini göstermeyi amaçlamaktadır.

\section{Memlükler Döneminde Hanefi ve Şâfiî Mezheplerinin Genel Durumu}

Bir Türk devleti olan Memlükler'de yeni bir uygulama olarak, her dört mezhepten de birer kadının tayin edildiği görülmektedir. Nitekim 663 (1265) yılında Memlük Sultanı Baybars, Şafii kâdılkudâta ilave olarak atadığı diğer üç mezhepten kadılarla önce Kahire'de, kısa süre sonra Dımaşk'da ve zamanla diğer şehirlerde dört mezhep uygulamasını fiilen başlatmış oldu (İbn Kesir, 1998, s. 460; Aynî, 2009, s. 407). Her ne kadar Eyyûbilerin son yıllarına doğru el-Melikü's-Salih Necmeddin (637647/1240-1249) tarafindan vakfedilen Sâlihiyye Medresesi'nde, dört mezhep fikhının okutulmaya başlanması ve Şâfii kâdılkudata, diğer mezheplerden naibler atanmasıyla dört mezhepten kâdılkudat uygulamasına geçişte zemin hazırlanmışsa da bu değişimin sebepleri konusunda farklı görüşler ortaya atılmaktadır (Yalçın, 2016, s. 26-27). Bazı kaynaklar bu uygulamanın sebebi olarak Şâfii kâdılkudat Taceddin İbn Bintü'l-Eazz'in kendi mezhebine muhalif olan hukukî kararları uygulama noktasındaki çekincesi ile sultanın görüşlerine değer verdiği Emir Cemâleddin Aydoğdu'nun (ö. 664/12669) diğer üç mezhepten de kadı ataması doğrultusundaki teklifini göstermektedir (İbn Kesir, 1998, s. 461; Aynî, 2009, s. 407). Bu durumun bir başka nedeni olarak Moğol saldırıları sebebiyle Şam ve Mısır'a yapılan göçlerle başta Hanefîler olmak üzere diğer mezhep müntesiplerinin sayısının artması ve görülecek davalarda mevcut Şafiî kadısının beğenilmeyen tavırları gösterilmektedir. Tâceddin es-Sübkî ise bu uygulamanın gerekçesi olarak sultanın Tâceddin İbn Bintü'l-Eazz'1 huzuruna davet ettiği halde gelmemesi ve sultanın Hanefî nâib edinmesi yönündeki emrine uymamasını göstermektedir (Taceddin es-Sübkî, 1992, s. 319). Öte yandan bu durumun mezhep rekabetinin bir sonucu olarak Eyyûbîler tarafından kurulan ve güçlendirilen Şafii ulemanın yargı sistemindeki gücünü kırmak ve böylece Şafii mezhebinin etkisini azaltmak olduğu da zikredilmektedir. (Yalçın, 2016, s. 29-31). Bu iddianın gerekçesi olarak Türklerin kurduğu Memlük devletinde genel itibariyle devlet adamları ve askerler arasında Hanefî mezhebinin yaygın oluşu nedeniyle sadece askerî davalara bakacak olan kadının Hanefîlerden atanmasının sorunu çözmeye yeteceği, buna rağmen özellikle Hanbelî ve Malikîlerin nüfus itibariyle sayısının az olmasına karşın yargıda ihtiyaç olduğu öne sürülerek dört mezhep uygulamasına geçildiği ileri sürülmektedir. Ayrıca bazı kaynaklarda geçtiği üzere dört mezhep uygulamasının sebebi ile ilgili olarak mevcut Şâfi kadının sert tutumu ve kendi mezhebine muhalif görüşleri uygulamak istememesinin de söz konusu kararın tek sebebi olarak gösterilemeyeceği ifade edilmektedir. Zira sultanın hoşnut olmadığı kâdılkudâtı azledip yerine daha itaatkâr ve mutaassıp olmayan bir kadı atayabilecekken hakkında şikâyet bulunan Şafii kadısını görevde bırakıp diğer 
mezheplerden kadı ataması bu sebebin geçerli bir sebep olmadığını göstermektedir (Tarsûsî, 1992, s. 15-16). Buradan hareketle Memlük devlet adamlarının genellikle Hanefî mezhebine mensup olmaları ve sultanların güçlenen Şafîi etkisini ve Şâfiîlerin yönetim üzerindeki baskısını zayıflatarak devleti yönetmeyi daha mümkün ve kolay kılmayı istemeleri bu uygulamanın altında yatan gerçek sebep gibi görünmektedir.

Dört mezhepten kadı atama uygulamasının dört mezhebin ve onların temsil ettiği itikadî yapının meşru ve eşit olduğunu kabul etmek anlamında olduğu, mezhep taassubunun kırılmasına, karşı görüşlerin birbiri hakkındaki husumetini engellemeye ve çatışmanın önünü keserek toplumsal nizamın sağlanmasına katkı sağladığı söylenmektedir (Sever, 2017, s. 128). Görünüşte bu şekilde algılansa da bu uygulama ne dönemdeki mezhep kavgalarını sona erdirmiş ne de tüm halkı memnun etmiştir. $\mathrm{Bu}$ uygulama özellikle mutaassıp Şafiiler tarafından hoş karşılanmamıştır. Zira Taceddin es-Subkî (ö. 771), Şafii kadısı İbn Bintü'l-Eazz'ın biyografisini verirken, dört mezhep tayini uygulamasını eleştirmekte ve Şafiî mezhebinin üstünlügünü ifade etmektedir. Bir Türk hükümdarın Dımaşk'a atadığ 1 kadı, Emeviyye Camii'ne Hanefî bir imam getirmek istemiş ancak halk caminin kapılarını kilitlemiş, bunun üzerine imam görevinden azledilmiştir. Sübkî’nin aktardığına göre Şam, Mısır ve Hicaz topraklarında Şafiî olmayan bir devlet yıkılmaya mahkûmdur. Zira ne zaman Şafiî olmayan bir sultan Şam'1 ele geçirse onun devleti kısa zamanda yıkılmıştır. Sübkî bu durumu Allah'ın bu belde halkına verdiği bir lütuf olarak değerlendirip Şam'1 ve Şafîiliği kutsayan bir tavırla anlatmaktadır. İbnü'l-Vekîl de Şafiî olmayan ve Mısır'da hüküm sürmek isteyenlerin kısa sürede öldürüldügü̈nü nakletmektedir. Nitekim Sübkî’ye göre Hanefî olan Memlük sultanı el-Melikü'l-Muzaffer Seyfeddin Kutuz, başa geçmiş ancak kısa bir süre sonra öldürülmüsştür. Bundan dolayı daha sonra başa geçen elMelikü'z-Zâhir Rükneddin Baybars ise sultan olduğu gün Şafî̂ mezhebini taklit etmiştir. Ancak Baybars'ın başlattığı dört mezhepten kadı uygulaması onu yine hazin sondan kurtaramamıştır. Sübkî dört mezhep uygulamasından duyduğu rahatsızlı̆g 1 ilginç nakillerle anlatmaktadır. Rivayete göre Sultan Baybars rüyasında İmam Şafîîyi görmüş ve Şafiî kendisine "Mezhebimi küçük düşürdün. Bu beldeler benim mi, senin mi? Seni ve zürriyetini kıyamete kadar sultanlıktan azlettim." demiştir. Gerçekten de çok geçmeden Baybars ve sonrasında hükümdar olan oğlu el-Melikü's-Saîd Berke b. Baybars vefat etmişlerdir. Baybars'ın soyu, saltanatı ellerinden kaçırmış ve fakirlik içinde yaşamlarını sürdürmüşlerdir. Yine başka bir rivayete göre Baybars'1 rüyasında gören bir kişi ona "Allah sana nası1 muamele etti?" diye sormuş o da "Dört kadı uygulamasından dolayı çok şiddetli azap etti." şeklinde cevap vermiştir. Ayrıca Sübkî, bir beldenin mevcut alışkanlığı batıl bir uygulama değilse bunu değiştirmenin doğru olmadığını da söyleyerek kanaatini açıkça ortaya koymuştur. (Sübkî, 1992, s. 319-321). Sübkî' nin naklettiği bu abartılı anlatılar esasen toplumda Şafîiliğin ne denli kemikleştiğini, bu düzende herhangi bir değişikliğe tahammüllerinin olmadığını, taassup derecesinde mezheplerine bağlı olduklarını net bir şekilde göstermektedir. Avamdan öte âlimler arasında bu kadar mutaassıp Şafîi/Eş'ârinin bulunduğu bir toplumda Hanbelî akaidinin ya da herhangi bir farklı düşüncenin büyük tepkiyle karşılaşacağını ön görmek çok da zor değildir.

Her ne kadar bu uygulama Şafiilere oranla daha az müntesibi olan Hanefîleri memnun edecek bir uygulama olsa da Hanefiler yine de bu uygulama ile tatmin olmamışlar ve Hanefîliğin devletin resmî mezhebi olmasını arzu etmişlerdir. Bu gayeleri doğrultusunda Memlük sultanlarını ikna etmek üzere eser telif eden müellifler bile bulunmaktadır. Nitekim Hanefî̀ kâdılkudâtlarından Necmeddin et-Tarsûsî (ö. 758/1328) Tuhfetü't-Türk fimâ yecibü en yu'mele fi'l-mülk adlı eserinde, devletin bekâs1, müesseselerin tanzimi ve korunması, halkın menfaatlerinin muhafazas1, Türk saltanatının devamı, sultana bağlılı̆̆ın sağlanması açısından, o zamana kadar siyasî alanda daha çok tercih edilen Şâfiî mezhebine göre Hanefî mezhebinin çok daha uygun olduğunu ispat etmeye çalışarak Hanefîliğin devletin resmî mezhebi olmasını teklif etmektedir. (K1lıç, 2011, s. 114; Tarsûsî, 1992, s. 18). Babas1 da bir kadılkudat olan ve babasının kendisi lehine görevden çekilmesiyle vefatına kadar Hanefî kâdılkudâtı olarak görev yapan Necmeddin et-Tarsûsî, Memlük Sultanını teklifi doğrultusunda ikna etmek için bazı fikhî meselelere dair Hanefî̀ ve Şâfiî yorum farklılı̆̆ını kullanmıştır. Nitekim bunlar arasında imametin Kureyşiliği meselesi dikkat çekmektedir. Tarsûsî, içlerinde meşhur muhaddis Nevevî'nin de bulunduğu pek çok Şafiî’nin imametin Kureyşliliğini savunduğu bu nedenle de esasen Türk olan Memlük sultanlarının emirliğini kabul etmediklerini iddia etmektedir. Hatta bununla da 
yetinmeyip Şâfiîlerin şer'an kabul etmedikleri sultanların verdikleri mansıplarda görev yaptığını da kınayarak ifade etmektedir. Hâlbuki Şâfiîler, Kureyşî olmanın devlet başkanlığı için değil imâmet için şart koşulmuş olduğu kanaatindedir. Memlük sultanları halife olmayıp, Kahire'deki Abbasî halifesi onları göreve getirmiş ve kendi adlarına ülkeyi yönetmelerini istemiş̧ir. Buna göre Şâfîilerin Memlük sultanlarını tanımama gibi bir durum söz konusu değildir. Aynı şekilde Tarsûsî, Hanefilere göre savaş durumunda sultanın, zenginlerin mallarından -rızaları gözetilmeksizin- alabileceğini ifade etmekte buna karşın Şafii mezhebinde buna izin verilmediğini bildirmektedir. Nitekim Şâfiî âlimler İbn Abdilber ve İzzeddin b. Abdüsselam, Moğol saldırıları esnasında Memlük sultanları, Seyfeddin Kutuz ve Muhammed b. Kalavun'un zenginlerin mallarından almalarına izin vermemişlerdir. Ayrıca Şafiilerin aksine Hanefîlerin cuma ve bayram namazlarının sultanın ya da naibinin izni ile kılınmasını şart koştukları, kimsenin mülkiyetinde olmayan ölü araziyi ekerek canlandıran kimsenin ancak sultanın izni ile oraya sahip olabileceği, fethedilen yerdeki cizye ve toprakların devlete kalacağı ifade edilerek Hanefîliğin siyasi otoritenin güçlenmesi adına daha uygun bir mezhep olduğu, Şafii mezhebinin devletin yanında olmadığı izlenimi verilerek anlatılmaya çalışılmaktadır (Tarsûsî, 1992, s. 26-32).

Söz konusu fikhî meseleler aslında mezheplerin yorum farklılığından ileri gelmektedir. Kaldı ki Hanefî mezhebinin de devletin aleyhine yorumlanabilecek hükümleri bulunabilmektedir. ${ }^{1}$ Ancak burada önemli olan VIII. asır âlimlerinden bir kâdılkudâtın sadece devleti ilgilendiren meselelerde değil pek çok konuda oluşabilecek olan bu yorum farklılığını, Hanefî̀ mezhebinin devletin yanında ve siyasi otoriteye en uygun mezhep gibi gösterirken, Şâfiî mezhebinin devletin karşısında olduğunu ima etmesidir. Bu durum esasen Memlükler döneminde Hanefîliğin durumunu, mezhep farkının âlimler arasında geldiği noktayı ve mezhep taassubunu göstermesi bakımından oldukça dikkat çekicidir.

Hanefî ve Şâfîler arasındaki tartışmaların, karşılıklı olarak birbirlerine reddiye yazma şeklinde de gerçekleştiği görülmektedir. Bu durum Memlük döneminden çok daha önce başlamıştır. Nitekim İmamü'l-haremeyn Cüveynî (ö. 483/1091) Hanefilere karşı bir risale kaleme almıştır. İlerleyen zamanlarda Hanefi âlim Sıbt İbnü'l-Cevzi (ö. 654/1257) de Şâfîilere reddiye yazmıştır. Ayrıca söz konusu reddiyelerin zaman zaman Hanefî olan Türk sultan ve emirlerden destek gördügünü söylemek de mümkündür. Zira Emir Sargıtmış en-Nâsırî (ö. 659/1261) Hanefi kadılkudatı Siraceddin Ömer b. İshak el-Gaznevî'den (ö. 773/1372), Fahreddin er-Razi'nin (ö. 606/1210) Hanefilere karşı yazmış olduğu risaleye reddiye yazmasını istemiştir (Tarsûsî, 1992, s. 23-24).

Öte yandan her ne kadar Memlükler döneminde gerek dört mezhebin her birine birer kâdılkudât uygulaması, gerekse Memlük sultanlarının genellikle Hanefi mezhebi mensubu olmaları gibi nedenlerle Hanefîlerin, ayrıcalıklı bir konuma geldiklerini söyleyebilsek de bu durumu genellemek uygun olmaz. Zira Makrizî, Memlük sultanı, Nâsırüddin Muhammed b. Kalavûn'un mutaassıp bir Hanefî muhaddis ve fakih İbnü’t-Türkmânî'nin emirlerle çok sık bir araya gelmesinden hoşlanmadığını nakletmiştir (Makrizî, 1997, s. 114). Bu durum bir takım imtiyaza sahip olan Hanefîlerin Memlük sultanlarının iç işlerine fazlaca karışmasının doğurduğu bir hoşnutsuzluk olarak açıklanabilir. Nitekim J. Nielsen de Hanefîlerin bu tutumu gereği 700 (1301) ile el-Melikü'z-Zâhir Seyfüddîn Berkuk'un (ö. 801/1399) tahta çıktığı 784 (1383) yılları arasında Şafiilerden sadece sekiz kâdının görev yaptığını buna karşın Hanefîlerden aynı süre içerisinde on dört kâdının göreve getirildiğini belirterek bu duruma işaret etmektedir. Bu süre içerisinde köklü Şâfiî İbn Cemâa ailesinden üç ferdin 64 yıl gibi uzun bir süre görev yapmasına rağmen Hanefî İbnü't-Türkmânî ailesinden üç neslin sadece 24 yıl görevde kalabilmesi dikkat çekicidir. (Nielsen, 1984, s. 176).

\section{Bazı Hanefî Muhaddisler}

Memlükler döneminde Şafii muhaddisler sayıca çoğunlukta olmakla birlikte Hanefî muhaddisler de devlet nezdinde son derece etkin konumdadır. Bahri Memlükler döneminde ilk olarak başlayan dört ayrı kadılkudat uygulaması ile Hanefî muhaddisler de kadı olarak tayin edilerek idarî yapı içerisindeki konumlarını sağlamlaştırmışlardır. Bu dönem İslâmî ilimlerin genelinde olduğu gibi hadis alanında da

\footnotetext{
${ }^{1}$ Nitekim Şâfîilerin aksine yetim mallarından zekât alınmaması, kimsesi olmayanların mirasının devlete değil de yakın akrabalarına kalması gibi bazı hususlar bunlar arasında zikredilebilir. (Tarsûsî, 1992, s. 35-37).
} 
pek çok âlimin yetiştiği bir dönemdir. Bunlar arasında İbnü’t-Türkmânî (ö. 750/1350), Moğultay b. K1lıç (ö. 762/1361), Abdullah b. Yusuf ez-Zeylâî (ö. 762/1361), Aynî (ö. 855/1452), İbn Kutluboğa (ö. 879/1475) gibi meşhur Hanefî muhaddisler, kaleme aldıkları telif, tahriç, ihtisar ve şerh türü eserlerde dönemin âlimleri arasında hatırı sayılır bir mevkii teşkil etmişlerdir. Bu âlimlerden önde gelenleri hakkında kısaca bilgi vermek yerinde olacaktır.

\section{Alâeddin İbnü't-Türkmânî (ö. 750/1350)}

Dönemin ilmî bir muhiti sayılan Mardin'de 683 (1285) yılında dünyaya gelen Ali b. Osman b. İbrahim el-Mardinî, aslen Mardinli olup ailesi Kahire'ye göç etmiştir. Mardin'den Mısır'a giden Türkmen soyundan oldukları için (Dölek, 1992, s. 17) ailesinin diğer fertleri gibi kendisi de "İbnü’t-Türkmân̂̂" nisbesiyle tanınmıştır. İlimle meşgul olan bir ailede yetişen İbnü't-Türkmânî'nin babası Fahreddin Osman b. İbrahim (ö. 731/1331) meşhur Mısır Hanefî fakihi ve müderrisidir. Nitekim o, Muhammed b. Hasan eș-Șeybânî'nin el-Câmiu'l-kebîr adlı eserine șerh yazmıș ve bu eserini Mansuriyye Medresesi'nde okutmuştur (Safedî, 2000, s. 306). İbnü't-Türkmânî'den iki yaş büyük olan kardeşi Ahmed b. Osman (ö. 744/1344) da, hadis, fikıh, nahiv, edebiyat, mantık gibi çeşitli ilim dallarıyla meşgul olmuş bir âlimdir. Dimyâtî, İbnü'ş-Şıhne, İbnü's-Savvâf gibi muhaddislerden hadis dinlemiş kendisi de hadis rivayetinde bulunmuştur. Kendisinden rivayette bulunan muhaddisler arasında Zehebî de bulunmaktadır. Mısır kâdı'l-kudât naibliği de yapan ve babasının Mansuriyye Medresesi'ndeki müderrislik görevini üstlenen (İbn Kesir, 1998, s. 340-341) Ahmed b. Osman'1n pek çok eseri bulunmaktadır (Zehebî, 1990, s. 56-57; Safedî, 2000, s. 121-122; İbn Kesir, 1998, s. 340-341; İbn Hacer, 1993, s. 198; Süyûti, 1967, s. 469).

Kardeşi Ahmed ile birlikte tahsiline babasından fikıh okuyarak başlayan İbnü't-Türkmânî (Safedî, 2000, s. 326) Dimyâtî, İ́bnü's-Savvâf, Şehâbeddin el-Muhsinî, Ebü'l-Abbas Ahmed b. İbrâhim esSerûcî ve İbn Kayyim el-Cevziyye gibi âlimlerden istifade etmiş; tefsir, hadis, fıkıh, feraiz, Arap dili ve şiirle meşgul olmuş, özellikle hadis, fikıh ve aklî ilimlerde asrının önde gelen âlimlerinden sayılmıştır. (İbn Tağriberdî, 1992, s. 193; Polat, 2000, s. 234-235). Zeylaî (ö. 762/1320) ve Abdulkadir el-Kureşî (ö. 775/1373) gibi Hanefî fakih ve muhaddislerin yanında Irâkî (ö. 806/1403) gibi Şafii muhaddislere de hocalık yapmıştır. Nitekim Irâkî'nin Buhârî'nin el-Câmiu's-Sahih adlı eserini İbnü'tTürkmânî' den semâ ettiği nakledilmektedir. (İbn Fehd, ts, 126). Çeşitli yerlerde müderrislik yapan İbnü't-Türkmânî, 748 yılında Zeynüddin el-Bestâmî'den boşalan Misır Hanefî kadılkudatlığına getirilmiş ve vefatına kadar bu görevini ifa etmiştir. (Safedî, 2000, s. 206; İbn Hacer, 1993, s. 84; İbn Tağriberdî, 1992, s. 193). İbnü't-Türkmânî'nin oğulları İzzeddin Abdülaziz ve Cemaleddin Abdullah da ilimle özelde hadisle meşgul olmuş İzzeddin b. Cemaa, Abdullah için, Kamiliyye Medresesi'ndeki müderrislik görevinden feragat etmiştir. Babasının vefatından sonra da Mısır Hanefî kadılkudatlığı görevini de üstlenen Abdullah'ın Memlük sultanları nezdinde hatırı sayılır bir mevkii olduğu ve Şafii olan İbn Hacer'in, kendisinden sonra Hanefîlerden onun gibisinin gelmediği övgüsünden (İbn Hacer, 1993, s. 276) hareketle de Şafiilerle olumlu münasebetlerinin bulunduğu anlaşılmaktadır.

Pek çok eser telif eden İbnü't-Türkmânî'nin Beyhâkî'nin Sünenü'l-Kübra adlı eserine yönelttiği eleştirilerin yer aldığ el-Cevherü'n-nakî fi reddi ale'l-Beyhakî, İbnü's-Salah'ın Ulûmu'l-hadis adlı eserinin muhtasarı niteliğinde olan el-Müntehâb fì ulûmi'l-hadis, Tahrîcu ehâdisi'l-Hidâye, Behcetü'lerîb fì beyâni mâ fì Kitâbillahi mine'l-garîb, bu eserlerinden sadece bir kaçıdır. el-Kifâye fi muhtasari'l-Hidaye ismiyle Merginânî'in (ö. 593/1196) meşhur eseri el-Hidâye'nin şerhine başladığ1 ancak vefatı sebebiyle bitiremediği eserini oğlu Abdullah'ın tamamladığı da nakledilmektedir. (Safedî, 2000, s. 206; Kureşî, 1993, s. 582-583; İbn Kutluboğa, 1992, s. 211; Polat, 2000, s. 234-235).

Babası, kardeşi, oğulları ve torununun çeşitli yerlerde müderrislik ve kadılık görevlerini üstlendikleri göz önüne alındığında İbnü’t-Türkmânî ailesinin yaşadığı dönemde etkin bir Hanefî ailesi olduğunu söylemek mümkündür.

\section{Abdullah b. Yusuf ez-Zeylâî (ö. 762/1361)}

Doğum yeri ve tarihi hakkında fazla bilgi olmamakla birlikte nisbesinden anlaşıldığı üzere Zeylaî, aslen Somali bölgesinde Aden körfezi sahilinde bir liman şehri olan Zeylâ'dandır (Sifill, 2013, s. 352354). Suyutî’nin Tabakâtü'l-huffâz adlı eserinde Zeylâ̂’nin biyografisini 723-749 (1323-1348) 
doğumlu kişilerin oluşturduğu bir sonraki tabakada zikretmesi gerektiği halde vefatı sebebiyle bir önceki tabakada zikrettiğini ifade etmesi (Süyûti, 1994, s. 535) ve babas1 Yusuf ez-Zeylaî'nin 720 yılından önce vefat ettiği bilgisinden hareketle (Kureşî, 1993, s. 645) Zeylaî’nin 720'li yıllarda doğduğunu söylemek mümkündür (Sifil, 2013, s. 352). Osman b. Ali ez-Zeylaî, Alaeddin ibnü’tTürkmânî, Bahaeddin İbn Akîl ile dönemin meşhur muhaddisleri Zehebî ve Mizzî’den ders alan Zeylaî, hadis, fikıh, Arap dili ve nahiv gibi çeşitli ilimler tahsil etti. Fetva veren, ders okutan ve eser telif eden Zeylaî'nin en meşhur eseri el-Hidâye'nin hadisleri üzerine yapmış olduğu tahriç çalışmasıdır. Nasbü'r-râye li tahrîci ehâdisi'l-Hidâye adını verdiği ve üzerine İbn Hacer ve Kasım b. Kutluboğa tarafindan tekmil ve ihtisar yapılan bu eser, tahriç türünün en güzel örneklerinden kabul edilmektedir. Zeylaî eserinde sadece tahriç yapmamış, râvîlerin künye ve nisbelerine ve cerh ve tadil açısından durumlarına, rivayetlerdeki gizli kusurlara işaret ederek rical, hadis usûlü ve illet bilgisini, rivayetler arasında tercihte bulunarak da nâsih mensuh, muhtelifu'l-hadis ve fikhü'l-hadis alanlarındaki yetkin konumunu da ortaya koymuştur. ${ }^{2}$ Ayrıca Zeylaî, Nasbü'r-râye'de, el-Hidâye üzerine çalışması bulunan hocası İbnü’t-Türkmânî'nin eserde yapmış olduğu hatalara da dikkat çekerek tenkit etmiş̧ir (Acar, 2011, s. 77-99). Ahkâm hadisleri konusunda Zerkeşî, İbnü'l-Mülakkın, İbn Hacer ve Süyûtî gibi âlimler Nasbü̈ r-râye'den çokça istifade etmişlerdir. Zeylaî'nin, Zerkeşî’nin Keşşâf adlı tefsirindeki hadislerin tahricini yaptığı El-İs 'âf bi ehâdîsi' l-Keşşâf adlı eseri ile Muhtasaru Şerhi Me 'âni'l-âsâr kaynaklarda zikredilen diğer eserlerindendir. Zeylaî 762 yılında Kahire'de vefat etmiştir. (İbnü'l-Irâkî, 1989, s. 56; Makrizî, 1997, s. 258; İbn Tağriberdî, 1992, s. 9; Süyûti, 1967, s. 359; Tuğlu, 1996, s. 1-10).

İbn Hacer, hocası Irâkî’nin, Hanefî mezhebine mensup Zeylaî ile dostluğundan ve birbirleriyle olan yardımlaşmalarından bahsettiğini nakletmektedir. Buna göre Irâkî, Gazalî’nin İhyâ adlı eserindeki hadisler ile Tirmizî’nin ilgili bablarda başka rivayetlerin de olduğunu beyan ettiği yerlerin tahricinde Zeylaî'den; Zeylaî de el-Hidâye ve Keşşâf üzerine yaptığı tahriç çalışmalarında Irâkî'den istifade etmiştir. (İbn Hacer, 1993, s. 310; Süyûti, 1994, s. 535; Şevkânî, t.s., s. 402). İbn Hacer'in bu hususu ayrıca ifade etmesinden farklı mezhep mensubu bu iki âlimin dostluğu ve yardımlaşmalarının ilgisini çektiği anlaşılmaktadır.

\section{Moğultay b. Kılıç (ö. 762/1361)}

689 yılında ${ }^{3}$ Kahire'de dünyaya gelen Ebû Abdullah Alâeddin Moğultay b. Kılıç b. Abdullah, Türk asıllıdır. Küçük yaştan itibaren ilme meraklı olan Moğultay, babasının kendisini ok talimi yapması için göndermesine rağmen kaçıp ilim halkalarına katılmıştır. ${ }^{4} 700$ 'lü yıllardan itibaren ilim tahsiline başlayan Moğultay, 715 yılında da hadis eğitimi almaya başlamıştır (İbn Fehd, ts., s. 135). İbn Dakiku'l-id, Dimyâtî, Yusuf b. İbrahim ed-Debûsî (ö. 729/1328), Ebu'l-Hasan Nureddin Ali b. Ömer el-Vânî (ö. 735), Mizzî, İbn Seyyidünnâs gibi pek çok hocadan ders almış, ensap, Arap dili, şiir ve hadis ilimlerinde öne çıkmıştır. Bazı kaynaklarda ensap ilminde mahir olduğu ancak hadis ilminde behresinin az olduğu, yeteri kadar ilim tahsil etmediği de söylenen (İbn Rafi', 1982, s. 244; İbn Fehd, ts., s. 141; Süyûti, 1994, s. 538; İbnü'l-İmad, 1992, s. 337; Şevkânî, ts., s. 312-313). Moğultay, Hanefî muhaddis ve tarihçi olan İbn Kutluboğa tarafindan asrının imamı ve hafız olarak nitelendirilmiştir. (İbn Kutluboğa, 1992, s. 304).

Moğultay b. Kılıç, hocası İbnü's-Seyyidinnâs'ın (ö. 734/1333) vefatıyla boşalan Zahiriyye Medresesi'ndeki hadis kadrosuna atanmıştır. Hatib el-Kazvînî'nin (ö. 739/1338) dönemin sultanı ile görüşüp rica etmesi ile almış olduğu bu görev dolayısıyla Moğultay, tepkileri üzerine çekmiş, çokça tenkit edilmiştir. Bu görevi dışında Moğultay, Nâsıriyye, Ebû Huleyfe ve Sargıtamış medreseleri, Rükneddin Baybars Hankahı, Sâlihiyye Câmii, yine aynı zâtın tavassutu ile Kal'a Camii' gibi pek çok kurumda ders okutmuştur (İbnü'l-Irâkî, 1989, s. 72; İbn Kutluboğa, 1992, s. 305).

\footnotetext{
${ }^{2}$ Zeylâ̂'nin Nasbü'r-râye isimli eserinden hareketle hadis ilmindeki yetkinliğinin ortaya konulduğu bir çalışma için bk. (Tuğlu, 1996).

${ }^{3}$ Bazı kaynaklarda doğum yılının 690 veya 690'dan sonra olduğu nakledilmektedir. Bk. (İbn Fehd, ts., 133; İbn Tağriberdî, 1992, s. 8; Şevkânî, ts., s. 312).

${ }^{4}$ Babasının bir kılıç ustası olduğu ve oğlu Moğoltay’ı küçük yaştan itibaren asker olarak yetiştirmek istemesinden hareketle kendisinin ya da büyük dedelerinin Memlük olabileceği ile ilgili yorum için bk. (Tozlu, 2011, s. 37-43).
} 
Moğultay, dil ve hadis üzerinde çalışanlar için bir kaynak olarak nitelenen yüzden fazla eseri kaleme almıştır. En büyük meşgalesi okuduğu eserlerdeki hataları bulup düzeltmek olan Moğultay'ın ikmâl, ıslah, zeyl, zevaid, cem türü pek çok eseri bulunmaktadır. En önemli eserlerinden biri Mizzî’nin Tehzîbü'l-Kemâl adlı eserindeki hatalara işaret ederek ikmâl ettiği İkmâlü Tehzîbi'l-Kemâl adlı eserinden pek çok muasırı ve talebesi istifade etmekle birlikte Moğultay'ın tenkitlerinde sert olduğu, aşırıya gittiği ve bazı yerlerde de haksız yere eleştirdiği gibi nedenlerle eser tenkit edilmiştir. Hz. Peygamber'in siretine dair kaleme aldığ 1 ez-Zehrü'l-bâsim fí sîreti Ebi'l-Kâsım, İbnü's-Salâh'in Ulûmu'l-hadis adlı eseri üzerine yazdı̆̆ı Islâhu İbni's-Salâh fî Ulûmi'l-hadîs, el-ìlâm bi sünnetihi aleyhisselâm gibi çalışmaları kaynaklarda belirtilen onlarca eserden ${ }^{5}$ sadece birkaçıdır (İbnü' l-Irâkî, 1989, s. 72; İbn Hacer, 1993, s. 353; Kandemir, 2005, s. 229-231).

Moğultay'ın aşka dair yazmış olduğu el-Vâdıhu'l-mübîn fí men üstüşhide mine'l-muhibbîn adlı eseri ise onun çağdaşları arasında eleştiri ve alay konusu olmasına, bir süreliğine hapse girmesine ve kitaplarının piyasadan toplatılmasına sebep olmuştur. Eserde aşka dair kullandığı rivayetlerin sıhhat bakımından tenkit edilmesi ve Hz. Aişe ile Hz. Peygamber'in aşkı hakkında içerdiği bilgiler nedeniyle döneminde Moğultay, hadis bilgisi ve kişilik olarak zafiyet içinde olduğu eleştirilerine maruz kalmıştır. Esasen onun bu zor duruma düşmesine neden olan Türk asıllı Şamlı Şafii bir muhaddis olan Ebû Saîd Salâhuddîn Halîl b. Keykeldî el-Alâî’dir (ö. 761/1359). 745 yılında oğlu ile birlikte Kahire'ye gelen Alâî, çarşıda satılan kitaplar arasında Moğultay'ın söz konusu eserini görmüş ve eserde kullanılan hadislerin zayıf olduğu ve Hz. Aişe'yi layık olmadığı bir şekilde takdim ettiği gerekçesiyle Moğultay'ı kâdılkudât Muvaffakuddin Ebû Muhammed İbn Ebû Abdullah el-Hanbelî’ye (ö. 769/1367) şikâyet etmiştir. Moğultay'ı suçlu bulan kadı, onun hapse atılmasına ve eserin satışının yasaklanmasına karar vermiştir. Emir Bedreddin Canikli b. Muhammed el-Bâba'nın (ö. 746/1345) araya girmesiyle Moğultay serbest bırakılmıştır (İbn Hacer, 1993, s. 352; İbnü'l-İmad, 1992, s. 337).

Moğultay, ders aldığını bildirdiği Fahreddin el-Buhârî, Dimyâtî ve İbn Dakîku'l-îd'den aslında semâının bulunmadığı noktasında da bir takım tenkitlere maruz kalmıştır. Özellikle İbn Dakîku'lîd'den olan semâının tarihi açıdan mümkün olmadığı iddia edilerek yalanlanmıştır. Zira Moğultay 702 yılında Kamiliyye Medresesi'nde İbn Dakîku'l-îd'den semâda bulunduğunu ifade etmektedir. Ancak Irâkî hocası Takıyyüddin es-Sübkî'ye bu durumu sorduğunda onun, İbn Dakîku'l-îd'in 701 yılında rahatsızlandığını ve vefatına kadar da evine çekilerek orada yaşamını sürdürdügünü anlattığını nakletmektedir. Irakî bunun üzerine İbn Dakîku'l-îd'in hizmetinde bulunan Taceddin Abdürrezzâk'a bu durumu sorarak hocanın naklini teyid etmiştir (İbn Hacer, 1993, s. 353; İbn Fehd, ts., 136-137).

Bulkînî, Irâkî, İbnü'l-Mülakkin gibi VIII. asrın meşhur muhaddislerine hocalık yapan Moğultay b. K1lıç (İbn Hacer, 2002, s. 125) 762 y1lında Kahire'de vefat etmiş cenaze namazını Şâfii muhaddis ve kâdılkudat İzzeddin b. Cemâa (ö. 767/1366) kıldırmıştır (İbn Kesir, 1998, s. 633; İbn Fehd, ts., s. 141).

\section{Bedreddîn el-Aynî (ö. 855/1451)}

762 y1lında Gaziantep'de dünyaya gelen meşhur Buhârî şarihi Ebû Muhammed Mahmûd b. Ahmed Bedreddîn el-Aynî, ilimle meşgul olan bir aileye mensuptur. İlk eğitimini Gaziantep kadısı olarak görev yapan babasından alan Aynî, kendi beldesinde çeşitli hocalardan sarf, nahiv, fikıh, mantık, feraiz gibi çeşitli ilimleri tahsil etti. Bir süreliğine babasının yerine kadılık da yapan Aynî babasının vefatından sonra Halep'e ilim tahsili için yolculuk yaptı. Orada Cemaleddin Yusuf b. Musa el-Malâtî ve diğer bazı hocalardan ders aldı. 788/1386 yılında Halep'ten Kudüs'e geçen Aynî, orada Zahiriyye Medresesi ve Hankâhı'nın şeyhi Alâeddin Ahmed b. Muhammed es-Sîrâmî ile tanıştı. Aynî’nin Sîrâmî'den ders alması ve hocasının beğenisini kazanması, onun Kahire akademik çevresine dahil olmasına, tanınmasına ve ilmî hayatında önünün açılmasına imkân sağlamıştır. Zira Sîrâmî üst düzey yöneticilerle sıkı ilişkisi olan etkin bir âlimdi. Hocası ile birlikte Kahire'ye giden Aynî, burada tasavvufa intisap etti ve Zahiriyye sufilerinden biri oldu (İbn Tağriberdî, 1992, s. 286; Sehâvî, ts., s. 131; Broadbridge, 1999, s. 87)

\footnotetext{
${ }^{5}$ Basılı ve yazma tüm eserleri ve muhtevaları için ayrıca bk. (Tozlu, 2011, s. 89-151).
} 
Kahire'de adını duyurmaya başlayan Aynî, yöneticiler nezdinde de itibar kazanarak çeşitli idari görevlerde bulundu. 801 y1lında Makrizî yerine Kahire mühtesipliğine getirildi. Aynî'nin talebesi İbn Tağriberdî’nin de işaret ettiği gibi bu tayin sebebiyle Aynî vefatına kadar, muasırı meşhur tarihçi Makrizî ile olumsuz, düşmanca bir tavır içinde olmuşlardır. Aynî zaman zaman bu görevinden alınsa da tekrar göreve getirilmiş ayrıca evkâf nazırlığı ve başkadılık gibi görevlerde de bulunmuştur. (İbn Tağriberdî, 1992, s. 286-287; Koçkuzu, 1991, s. 271-272)

Aynî'nin iyi derecede Türkçe ve kısmen Farsça bilmesi sultanların teveccühünü kazanmasına imkân tanımıştır. Nitekim Aynî Arapça yazmış olduğu tarihini el-Melikü'l-Eşref Barsbay'a okuyup Türkçe açıklamasını yapmıştır. Sultan gerek tarih ile ilgili gerekse dinî konularda merak ettiği konuları Aynî ile müzakere etmiş hatta "Aynî olmasaydı İslâm adına hiçbir şey öğrenemezdik." diyerek Aynî'ye taltifte bulunmuştur. Barsbay'ın vefatından sonra görevinden azledilen Aynî evine çekildi ve 855 yılında Kahire'de vefat etti. Aynî'nin meşhur Buhârî şerhi Umdetü'l-kârî ve dönemin tarihi olaylarını anlattı̆̆ eseri İkdü'l-cümân başta olmak üzere pek çok eseri bulunmaktadır. (İbn Tağriberdî, 1992, s. 287; Sehâvî, ts., s. 131-135)

Memlükler dönemindeki Hanefî âlimler yukarıda geçen isimlerle sınırlı değildir. Biyografisi verilen âlimler dışında İsmâil b. İbrâhim Mecdüddin el-Belbîsî (ö. 802/1399), Bedreddin el-Aynî (ö 855/1451), Takıyyüddin Ebü’l-Abbas eş-Şümünnî (ö. 872/1468), Kâsım b. Kutluboğa (ö. 879/1474), Abdurrahman b. Ebû Bekir Zeynüddin el-Aynî (ö. 893/1487) gibi pek çok âlimi saymak mümkündür. Söz konusu âlimler hadis ilminin pek çok alanında eser telif etmiş, Memlük medrese ve darulhadislerinde hocalık yaparak hadis ilmine katkı sağlamışlardır. ${ }^{6}$

\section{Muhaddislerin Birbirleriyle Olan İlişkilerinde Mezhep Farklılığı}

Memlükler döneminde farklı mezheplere mensup çok sayıda âlimin, ilmî ve idarî mevkii açısından bir âlimin gelebileceği en üst düzeye erişebilme arzusu içinde olmaları, ciddi bir akademik rekâbet ortamı oluşturmuştur. $\mathrm{Bu}$ ortam içinde âlimler gerek telif eserleri vasıtasıyla gerekse bir araya geldikleri ilim meclislerinde birbirlerini tenkit etmekten, tartışmaktan geri durmamışlardır. Esasen ilmî tartışmalar, durağan bir ilmî çevreden ziyade fikir hareketliliğinin ve canlılığın olduğunun en önemli göstergesidir. Ancak insanî bir duygu olan daha iyi olma arzusuna mezhep taassubu da eklenince söz konusu âlimlerin hayat hikâyeleri arasında, muasırlarıyla olan münasebetlerinde istihfaf ve müstehzi bir tavrın sergilendiği bazı olumsuz örnekler de bulunmaktadır (Aynî, 1989, s. 22-23).

Daha önce bahsi geçen Moğultay b. Kılıç’ın yazmış olduğu eserden dolayı yaşadığı tatsızlı̆̆ın temelinde mezhep farklılığı olduğu akla gelmektedir. Zira Moğultay'ın yazdığı eserinde zayıf ve asılsız rivayetler ile Hz. Aişe'ye yakışmayan bir uslüp kullandığ 1 gerekçesiyle kadıya şikâyet eden, Şâfiî bir muhaddis Ebû Saîd Halil b. Keykeldî el-Alâî'dir. Bu zât Moğultay'1 bazı hocaları ile karşılaşmadığı halde onlardan semâının bulunduğunu iddia ederek de eleştirmektedir (İbn Hacer, 2002, s. 125). Bu şikâyet ve eleştiriden bu iki muhaddis arasında bir çekişme olduğunu anlaşılmaktadır. Nitekim Kevserî Moğultay'ın Hz. Aişe'ye yakışmayan bir söz söylemesinin mümkün olmadığını düşünen ve onu hapisten kurtaran emirden söz ederken bu gibi anlaşmazlıkların akranlar arasında sıkça yaşandığını bunun temel sebebinin mansıp kavgası ve mezhep farklılığ olduğunu ifade etmektedir. Üstelik Kevserî Moğultay'ın, Zahiriyye Medresesi'ndeki hadis kadrosuna atanmamış olması durumunda belki de bu tür tatsız bir olayın hiç yaşanmayacağına dair kanaatini de açıkça dile getirmektedir. Bununla birlikte Moğultay'ın bazı hocalarından semâı bulunmadığını iddia eden Alâî, Irâkî ve diğer âlimlerin öne sürdükleri delillerinin kuvvetli olmadığını dile getiren Kevserî, bir âlimin eleştirilere maruz kalmasıyla kıymetinden hiçbir şey kaybetmeyeceğini de ekleyerek, Moğultay'1 gerek söz konusu kitabı gerekse bazı hocalarından semâı bulunmadığı yönünde eleştirenleri tenkit etmektedir (İbn Fehd, Dımaşk ts., s. 137-140).

Birbirine muasır olan iki büyük muhaddis Aynî ve İbn Hacer bu tür bir rekabet ortamının izini sürmek adına önemli iki âlimdir. Zira eserleriyle ilim dünyasına büyük katkıları olan ve sonraki asırlarda, çalışmaları kaynak eser olarak kullanılan söz konusu âlimlerden Aynî mutaassıb bir Hanefî, İbn Hacer

\footnotetext{
${ }^{6}$ Hanefî muhaddislerin, hadis usülüne katkılarını görmek için ayrıca bk. (Özben, 2016, s. 1-31).
} 
ise Şafii mezhebine mensup bir muhaddistir. Bu iki âlimin ayrı mezheplerden oluşu, aralarındaki rekâbetin artmasının en önemli sebeplerinden biridir. Bu âlimlerin farklı bakış açıları ve görüşleri telif ettikleri eserlerine de yansımış, birbirlerini telifâtları üzerinden tenkit etmişlerdir. Nitekim İbn Hacer'in meşhur Buhârî şerhi, Fethu'l-bârî'de özellikle ahkâm hadislerin şerh ve tevilinde kendi mezhebini desteklemeye çalışması ve yeri geldikçe Hanefîleri eleştirmesi, muasırı Aynî'yi eseri hemen temin edip incelemeye sevk etmiş ve akabinde İbn Hacer'e yönelttiği tenkitleri yine bir Buhârî şerhi olan Umdetü'l-kârî'nin başında zikretmiş̧ir. İbn Hacer ise Aynî'nin tenkitlerine cevap vermek üzere İntikâdü'l-i 'tirâz adlı eserini kaleme almıştır (Sakallı, 1996, s. 137).

Aynî ile İbn Hacer'in birbirlerine karşı sert ve acımasız tutumları birbirlerine karşı ortaya attıkları intihal iddiasında da görülmektedir. Nitekim öncelikle Aynî, İbn Hacer'in Fethu'l-bârî'sini yazarken Türk âlim Şemseddin Muhammed b. Yûsuf el-Kirmânî'nin (ö. 786/1384) el-Kevâkibü'd-derârî adlı Buhari şerhinden isim vermeden istifade ettiğini öne sürmüş hatta "Kirmânî'nin şerhi olmasaydi İbn Hacer' in Buhari şerhini tamamlayamayacağını" iddia etmiştir (Sakallı, 1996, s. 85). İbn Hacer ise Aynî'nin tenkitlerine cevap verdiği eseri İntikâdü'l-i ‘tirâz'da Aynî’nin eserini 820 yılında, kendi şerhini elde ederek yazmaya başladığını, hatta ilk iki cildi bir yıl gibi kısa bir süre içerisinde yazdığı halde üçüncü cildi on sekiz yıl sonra tamamlayabildiğini ifade etmiştir. Ciltlerin telifi arasındaki bu uzun sürenin ise Aynî’nin kendi yazdığı ciltleri temin edemeyişi olduğunu iddia etmektedir. İbn Hacer'e göre ne zamanki Aynî, İbn Hacer'in talebelerinden istinsah edilmiş bir Fethu'l-bârî nüshasını ödünç almış o zaman yazmaya kaldığı yerden devam etmiş ve asıl müellifine atıf yapmadan nakilde bulunmuştur (İbn Hacer, İntikâd, 1993, s. 10). Başka bir yerde ise İbn Hacer, Aynî’yi öfkesine yenik düşmekle ve anlayışının az olmasıyla itham etmiş ve ondan "gece uykusuz kalan ve bedenini bitkin düşüren bir şârihi hedef alan zâlim" olarak bahsetmiştir (İbn Hacer, İntikâd, 1993, s. 10). İbn Hacer yorucu ve uzun süren çalışmalarını çalan Aynî’yi zâlimlikle suçlamakta ve taassubun Aynî'nin gözlerini kör ettiğini ifade etmektedir (İbn Hacer, Intikâd, 1993, s. 30). Buna karşın Aynî de Umdetü'l-kârî'yi yazış amacını ifade ederken İbn Hacer'i kastederek sözü kötüleme ve çirkinliğe kadar vardırarak kitap tasnif edenlere cevap vermek şeklindeki sözlerine yer vermiş ayrıca İbn Hacer'i kibirli olmakla suçlamıştır (Sakallı, 1996, s. 51, 67).

Aynî ile İbn Hacer arasındaki anlaşmazlık müelliflerin diğer eserlerinde de hissedilmektedir. Nitekim Aynî İkdü'l-cümân fî tarihi ehli'z-zaman adlı eserinde Sultan el-Melikü'z-Zâhir Çakmak'ın (842857/1438-1453) oğlu Nâsırüddin Muhammed b. Çakmak'ın (ö. 847) biyografisini aktarırken İbn Hacer hakkında ağır ifadeler kullanmaktadır. Aynî, İbn Hacer ve bazı âlimlerin önemli bir göreve tayin edilmek için söz konusu veliahtın yaşadığı ve uzunca bir merdivenle ulaşılan Kal'atülcebel'e üşenmeden her Cuma günde iki üç kez çıktıklarını bu nedenle de İbn Hacer ve onun gibi görev için emirlere yakın durmaya çalışan âlimlerin halk tarafindan "fukahâü'l-atbâk (kışla fakihleri)"7 diye isimlendirildiğini alaycı bir üslupla aktarır. Ayrıca Aynî, bu tavırları sebebiyle içlerinde İbn Hacer'in de bulunduğu söz konusu âlimleri ilmin saygınlığını muhafaza etmekten yoksun olmakla itham etmektedir (Aynî, 1989, s. 25, 616-617).

Bu iki büyük âlim arasındaki çekişme edebiyat alanında da görülmektedir. Şiir ve Arap dilinde de eserler veren Aynî, Memlük sultanı el-Melikü'l-Müeyyed Şeyh el-Mahmûdî (1412-1421) ve dönemiyle ilgili es-Seyfü'l-mühenned fí sîreti'l-Meliki'l-Mü'eyyed adlı manzum bir eser kaleme almış akabinde İbn Hacer, eserde yer alan 400 kadar beyitteki rekâketi göstermek üzere Kaza'l- 'ayn min nazmi gurâbi'l-beyn adlı bir eser derlemiştir (Süyûti, 1965, s. 276; Kandemir, 1999, s. 528). Ayrıca Aynî, Müeyyediyye Medresesi'nde görev yaptığı sırada medresenin minaresi yıkılmış, İbn Hacer ise bu durumu göz değmesine (ayn/ أعين) bağlayarak yazdığı beyitte Aynî’ye tarizde bulunmuştur (Süyûti, 1965, s. 276). ${ }^{8}$ Aynî de İbn Hacer'in bu beytine Allah'ın takdiri ile olan bu olayın göz değmesine bağlanmasının hata olduğunu, ille de bir sebep aranacaksa bunun taşın (الحجر) yerinden düşmesi

\footnotetext{
${ }^{7}$ Memlüklerde satın alınan memlükler Kal'atülcebel'deki "tabaka” adlı kışlalarda eğitim görmektedir. Aynî de söz konusu sarayda yetişen askerlerden mülhem saraya sıklıkla giden âlimleri fukahâü'l-atbâk ifadesiyle nitelendiriyor olabilir. Bk. (Ayaz, 2015, s. 23).

${ }^{8}$ İbn Hacer'in yazdığı beyit şu şekildedir:

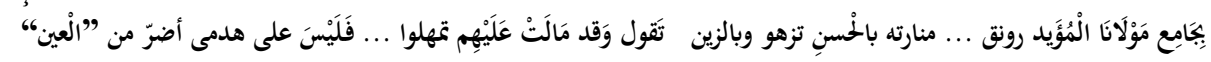


olduğunu ifade eden bir beyitle karşılık vererek İbn Hacer'in isminden hareketle aynı usulle onun kadılıktan azline işaret etmektedir (Süyûtî, 1967, s. 272; Sakall1, 1996, s. 58-59). ${ }^{9}$ Nüfûz sahibi bu iki âlimin birbirlerine yaptıkları bu tarizlerden anlaşılan o ki onları birbirlerine reddiye yazmaya sevk eden unsur sadece ilmî bir hatayı düzeltme arzusu değildir. Onların arasında gerek mezhep farklılı̆̆ından gerekse aynı dönemde yaşamış olmanın da körüklediği akademik rekabetten kaynaklanan bir anlaşmazlığın olduğu muhakkaktır. Nitekim Süyûtî de bu iki âlim arasında bir yarış olduğuna işaret etmektedir (Süyûti, 1965, s. 276).

Aynî’nin iyi geçinemediği bir diğer âlim ise Makrîzî’ dir (ö. 855). Önceleri Hanefî̀ mezhebine mensup olduğu halde Makrizî, dedesinin vefatı ile daha titiz olduğunu düşündüğü ve Mısır toplumunda daha yaygın ve baskın olan Şâfî mezhebine intisap etmiş ve hayatı boyunca Hanefîlere karşı bir tutum sergilemiştir (İbn Tağriberdî, 1984, s. 417; es-Seyyîd, 2003, s. 448; Broadbridge, 1999, s. 86). Mutaassıp bir Hanefî olan Aynî ile iyi geçinemeyen Makrîzî, 801 yılında el-Melikü'z-zâhir Berkûk tarafindan kendi yerine Aynî’nin Kahire mühtesibliğine tayin edilmesini kabullenememiştir. Diğer örneklerde olduğu gibi bu iki âlimin de eserlerinden de aralarındaki anlaşmazlığın izleri sürülebilmektedir. Nitekim bir yıl sonra bu kez Makrîzî bu göreve getirildiğinde Aynî, tarihinde 802 olaylarını anlatırken bu tayinden müstehzi bir uslüpla söz etmekte ve daha önce bu göreve Makrîzî yerine kendisinin getirildiğini de vurgulamaktadır (Aynî, 1989, s. 27). Buna karş1lı Makrîzî Sülü̈k adlı eserinde Aynî’nin mühtesib olarak görev yaptığı 828 yılı olaylarını yazarken çarşılarda ekmeğin azaldığını bu nedenle halkın ayaklanıp isyan ettiğini ve Mühtesib Aynî’yi emirlere şikâyet ettiklerini bildirmektedir. Bunun üzerine sultanla arası iyi olan ve her gece sultanla bir araya gelip tarih kitaplarını Türkçeye tercüme ederek okuyan Aynî halk tarafından taşa tutulmaktan korktuğu için kaleye sığınmıştır. Sultan Aynî’yi himaye ederek adamlarıyla halkı yatıştırmış ancak çıkan kavgada halktan yirmi iki kişi tutuklanmıştır. Makrizî, bir gece hapsedilen ve kötü muameleye tabi tutulan söz konusu kişilerin ertesi gün salındığını ancak bu olayın halk nazarında Aynî’nin kötü anılmasına, kalplerdeki mevkiini kaybetmesine neden olduğunu da ilave etmiştir (Makrizî, 1997, s. 123). Makrizî'nin Aynî'nin düştüğü bu zor durumu onunla olan anlaşmazlığı sebebiyle kasten anlattığ düşünülebilir. Zira bu tür ekonomik zorluklar ve halkın tepkisi her mühtesib zamanında olabilecek sıradan olaylardır. Sadece Aynî zamanında meydana gelmiş değildir (Aynî, 1989, s. 28). Kaldı ki muasır tarihçilerden İbn Tağriberdî de bu olayı naklederek Makrizî’nin, Aynî’nin taşlanmak istenmesine sessiz kaldığını ve esasen bu olayı Aynî’ye olan kini ve öfkesi nedeniyle zikrettiğini bildirmekte ve iki âlim arasında anlaşmazlık olduğunu da ilave ederek hocası Aynî’den yana durmaktadır (İbn Tağriberdî, 1992, s. 117-118). Buna karşılık Aynî, tarihinde 845 yılında vefat eden Makrizî'nin biyografisini yazarken aralarındaki sorunları unutmamış olacak ki Makrizî gibi önemli âlimlerin biyografilerine yer verdiği şekliyle uzunca bir vefeyat yazmamış üstelik onu küçümseyici tarzda ifadeler de kullanmıştır (Aynî, 1989, s. 28). Buradan hareketle bu iki âlim arasında da gerek mezhep taassubu gerekse akademik rekabetten kaynaklanan bir anlaşmazlık olduğunu söylemek mümkündür.

Farklı mezhep sahibi bazı âlimler arasında bir takım sorunlar yaşandığı açıkça gözlendiği gibi aynı mezhebe mensup âlimler arasında da benzer durumlar söz konusu olabilmektedir. Nitekim Abdullah $b$. Yusuf ez-Zeylâî ile Hanefî fâkihi Ebû Muhammed Abdülkâdir b. Muhammed el-Kureşî (ö. 775/1373) arasında da benzer bir anlaşmazlık olduğu görülmektedir. Zira Zeylâî, Hidâye üzerine yazdığı Nasbü' $r$-râye adlı meşhur eserinde isim vermeden yine Hidâye üzerine el-İnâye bi-ma 'rifeti ehâdîsi'lHidâye isminde eser telif eden akrânı Kureşî’yi eleştirmektedir. Hocası İbnü’t-Türkmânî'yi tenkit ettiği pek çok yerde hatanın esasen hocasından değil taklit ettiği bir cahilden kaynaklandığını ifade eden Zeylâî’nin, kast ettiği kişinin Kureşî olduğu söylenmektedir. Bu durumun sebebi olarak da İbnü't-Türkmânî'nin iki talebesi olan Zeylâî ile Kureşî arasındaki anlaşmazlık olduğu ifade edilmektedir. İbnü’t-Türkmânî’nin talebesi Kureşî’ye Zeylâî’den daha çok güvenmesinin iki talebe arasında bir rekabete dönüştüğü iddia edilmektedir. Bununla birlikte Hanefî tabakât yazarı Kureşî’nin eserinde Zeylâî'nin babasından bahsettiği halde Zeylâî'den hiç söz etmemiş olması söz konusu

9 Aynî’nin yazdığı beyit şu şekildedir:

منارة كعروس الحسن إذ جليت ... وهدمها بقضاء الله والقدر قالوا أصيبت بعين قلت ذا غلط ... ما أوجب المدم إلا خسة الحجر 
iddiaları doğrular niteliktedir (Acar, 2011, s. 77-99). Kaldı ki babası Yusuf ez-Zeylâî'den de birkaç satırla bahseden Kureşî Arapçayı iyi kullanamadığı için öfke ve cedel içinde olduğunu da ifade etmektedir (Kureşî, 1993, s. 645).

\section{SONUÇ}

Memlükler dönemi gerek yetişen âlimler gerekse telif edilen eserler bakımından İslâm kültür tarihinde ikinci altın çağ nitelemesini hak edecek kadar zengin bir dönemdir. İdarecilerin çoğunlukla Türk ve Hanefî olmasının da etkisiyle bu dönemde, dört mezhepten kâdılkudât tayini gibi bir takım uygulamalarla özellikle Eyyübîlerde yaygın ve siyasi açıdan ayrıcalıklı olan Şafii mezhebinin etkisi yavaş yavaş azalmaya ve gerek mensuplarının nüfusu gerekse idari kadrolara sahip olma itibariyle Hanefîlik lehte bir gelişim süreci takip etmiştir. Bu dönemde her ne kadar bu dönemde mensuplarının sayısının daha fazla olmasına bağlı olarak yetişen Şâfii muhaddisler sayıca Hanefîlere göre çok daha fazla olsa da bazı idarî kadroları ellerinde bulunduran, darülhadis ve medreselerde hocalık yapan, eserler telif eden önemli Hanefî̀ muhaddislerden de bahsetmek mümkündür.

Yukarıda ele alınan örnekler göz önünde bulundurulduğunda farklı mezhep mensubu mutaassıp bazı muhaddislerin birbirleriyle bir takım husumet ve anlaşmazlık yaşadığı, olayları kendi mezhebi lehine yorumlama eğiliminde oldukları, birbirlerine karşı zaman zaman hakarete varacak kadar ileri gittikleri anlaşılmaktadır. Aralarındaki bu husumet eserlerine de yansımakta ve birbirlerine karşı tarizde bulunma, yok sayma, müstehzi bir tavırla bahsetme, küçük düşürme gibi durumlar da göze çarpmaktadır. Buna rağmen aralarındaki anlaşmazlıkların tek sebebinin mezhep taassubu olduğunu söylemek mümkün değildir. Zira bu anlaşmazlıklar, aynı dönemde yaşamış, başarılı âlimlerin gerek darülhadis ve medrese hocalığı gibi eğitim-öğretim kadrolarında gerekse kâdılkudâtlık, mühtesib, beytülmâl nâzırlığı gibi idari kadrolara sahip olma ve halk nezdinde tercih edilme arzusundan doğan ve son derece fitrî olan akademik rekâbet duygusundan da kaynaklanmış olmalıdır. Kaldı ki benzer olayların aynı mezhep mensupları arasında gerçekleşebileceğini de gözden uzak tutulmamalıdır.

Bununla birlikte farklı mezhep mensubu âlimlerin tamamının birbiriyle iyi geçinmedikleri, sürekli münakaşa halinde oldukları da düşünülmemelidir. Nitekim İbn Hacer, hocası Irâkî’nin, Hanefî mezhebine mensup Zeylaî ile dostluğundan ve birbirleriyle olan yardımlaşmalarından söz ettiğini nakletmektedir. Irâkî, Gazzâlî'nin İhyâü ulûmi'd-dîn adlı eserindeki hadisler ile Tirmizî'nin esSünen'indeki bazı hadislerin tahricinde Zeylâ̂'den; Zeylaî de el-Hidâye ve el-Keşşâf üzerine yaptığ1 tahric çalışmalarında Irâkî' den istifade etmiştir. (Süyûtî, 1994, s. 535) Bu örnekte olduğu gibi farklı mezheplerden olan muhaddislerin, biyografi müelliflerini hususen işaret etmeye sevk edecek şekilde dostluk kurdukları ve birbirleriyle yardımlaştıkları, birbirlerine hocalık-talebelik yaptıkları, zaman zaman yaşadıkları sorunlara rağmen beşerî ve sosyal ilişkilerini olumlu düzeyde devam ettirdikleri, eserlerinde birbirlerinden övgü ile söz ettikleri de kaynaklarda yer almaktadır. Bu açıdan bakıldığında herhangi bir genellemeye gitmeden farklı mezhep mensubiyetini ve taassubunu, muasır âlimler arasında mevcut olan rekâbet duygusunu körükleyerek daha da ileri götüren bir unsur olarak değerlendirmek mümkündür.

Bilgilendirme / Acknowledgement: Bu makale IV. Uluslararası Şeyh Şaban-1 Veli Sempozyumu'nda sunulan bildirinin gözden geçirilmiş ve genişletilmiş halidir. 


\section{KAYNAKÇA}

Acar, Y. (2011). Zeylâ̂’nin İbnü’t-Türkmânî ile Kuraşî eleştirileri ve üç hadisçi arasındaki ilişkiler. Marife, (2), 77-99.

Ayaz, F. Y. (2015). Memlükler (1250-1517). İstanbul: İSAM Yayınları.

Aynî, M. (1989). ‘'ikdü'l-cümân fî tarihi ehli'z-zaman. (thk. Abdürrâzık el-Tantavî el-Karmut). Kahire: ez-Zehra li'l-I'lami'l-Arabî.

Aynî, M. (2009). 'İkdü'l-cümân fì tarihi ehli'z-zaman. (thk. Muhammed Muhammed Emin). Kahire: Darü'l-kütüb ve'l-vesâikü'l-kavmiyye.

Bardakoğlu, A. (1997). Hanefî mezhebi (kuruluşu ve yayılması, doktrinin gelişimi, usulü, genel karakteristiği. TDV İslâm Ansiklopedisi (DİA) içinde (c. 16, ss. 1-21). İstanbul: Diyanet Vakfi Yayınları.

Broadbridge, A. F. (1999). Academic rivalry and the patronage system in fifteenth-century Egypt: al'Aynî, al-Maqrîzî, and Ibn Hajar al-'Asqalanî. Mamluk Studies Review, (III), 85-107.

Dölek, A. (1992). .İbnü’t-Türkmân’̂’nin Beyhakî ile hadis sahasındaki ilişkileri. Yayınlanmamış yüksek lisans tezi, Erciyes Üniversitesi SBE, Kayseri.

Es-Seyyîd, E. F. (2003). Makrîzî. TDV İslâm Ansiklopedisi (DİA) içinde (c. 27, ss. 448-451). İstanbul: Diyanet Vakfi Yayınları.

Et-Tarsûsî, İ. (1992). Tuhfetü't-Türk fìmâ yecibu en yu 'mele fi'l-mülk. (thk. Rıdvan es-Seyyid). Beyrut: Dârü’t-Talîa.

İbn Fehd, M. (ts.). Lafzu'l-elhâz bi zeyli Tabakâtü'l-huffâz. Dımaşk.

İbn Hacer, A. (1993). ed-Dürerü'l-kâmine fí a 'yâni'l-mieti's-sâmine. Beyrut: Darü'l-cil.

İbn Hacer, A. (1993). el-İntikâdü'l-i 'tirâz fi'r-red ale'l-Aynî fî şerhi'l-Buhârî. (thk. Hamdi Abdülmecid es-Selefî, Subhi b. Câsim es-Sâmirâî). Riyad: Mektebetü'r-Rüşd.

İbn Hacer, A. (2002). Lisânü'l-Mîzân. (thk. Abdülfettah Ebû Gudde). Beyrut: Mektebü'l-Matbuati’lİslâmiyye.

İbn Kesir, İ. (1998). el-Bidaye ve'n-nihaye. (thk. Abdullah b. Abdülmuhsin). Suudi Arabistan: Daru'lhicr.

İbn Kutluboğa, K. (1992). Tâcü't-terâcim. (thk. Muhammed Hayr Ramazan Yusuf). Dımaşk: Dârü'lKalem.

İbn Rafi‘, M. (1982). el-Vefeyât. (thk. Salih Mehdi Abbas, Beşşar Avvad Ma'ruf). Beyrut: Müessesetü’rRisâle.

İbn Tağriberdî, Y. (1984). el-Menhelü's-sâfî ve'l-müstevfî ba 'de'l-vâfì. (thk. Muhammed Muhammed Emin). Kahire.

İbn Tağriberdî, Y. (1992). en-Nücûmu'z-zahire fì mülûkî Mısır ve'l-Kahire. (thk. Muhammed Hüseyin Şemseddin). Beyrut: Daru'l-kütübi'l-ilmiyye.

İbnü'l-Irâkî, A. (1989). ez-Zeyl ale'l-İber fi haberi men aber. Beyrut: Müessesetü'r-risâle.

İbnü'l-İmad, A. (1992). Abdülhay b. Ahmed, Şezeratü'z-zeheb fi ahbari men zeheb. (haz. Abdülkadir Arnaut-Mahmûd Arnaut). Beyrut: Dâru İbn Kesir.

Kandemir, M. Y. (1999). İbn Hacer. TDV İslâm Ansiklopedisi (DİA) içinde (c. 19, ss.528). İstanbul: Diyanet Vakfi Yayınları.

Kandemir, M. Y. (2005). Moğultay b. Kılıç. TDV İslâm Ansiklopedisi (DİA) içinde (c. 30, ss. 229-231). İstanbul: Diyanet Vakfi Yayınları. 
K1lıç, M. (2011). Tarsûsî, Necmeddin. TDV İslâm Ansiklopedisi (DİA) içinde (c. 40, ss. 114). İstanbul: Diyanet Vakfi Yayınları.

Koçkuzu, A. O. (1991). Aynî, Bedreddin. TDV İslâm Ansiklopedisi (DİA) içinde (c. 4, ss. 271-272). İstanbul: Diyanet Vakfi Yayınları.

Kureşî, A. (1993). el-Cevâhiru'l-mudiyye fi tabakâti 'l-Hanefiyye. Daru Hicr.

Makrizî, A. (1997). es-Sülûk li ma 'rifeti düveli’l-mülûk. (thk. Muhammed Abdülkadir Atâ). Beyrut: Darü'l-kütübi'l-ilmiyye.

Nielsen, J. S. (1984). Sultan al-zahir Baybars and the appointment of four chief qadis, 663/1265. Studia Islamica, (60).

Özben, Z. (2016). Hanefîler'in Mukaddime temelli hadis usulü literatürüne katkısı. İslâm Araşttrmaları Dergisi, 36, 1-31.

Polat, S. (2000). İbnü’t-Türkmânî, Alaeddin. TDV İslâm Ansiklopedisi (DİA) içinde (c. 21, ss. 234-235). İstanbul: Diyanet Vakfi Yayınları.

Safedî, H. (2000). el-Vâfi bi'l-vefeyât (thk. Ahmed el-Arnavut, Tezkî Mustafa). Beyrut: Daru İhyâi'ttürâsil-arabî.

Sakallı, T. (1996). Hadis tartışmaları (İbn Hacer-Bedruddîn Aynî). Ankara: Türkiye Diyanet Vakfı Yayınları.

Sehâvî, M. (ts.). ed-Dav'ü'l-lâmi 'li ehli'l-karni 't-tâsi '. Beyrut: Darü’l-Cîl.

Sever, M. (2017). Bahrî Memlükler dönemi mezhep hareketleri (1250-1382). Yayımlanmamış doktora tezi, Ondokuz Mayıs Üniversitesi SBE, Samsun.

Sifil, E. (2013). Zeylaî, Abdullah b. Yusuf, TDV İslâm Ansiklopedisi (DİA) içinde (c. 44, ss. 352-354). İstanbul: Diyanet Vakfi Yayınları.

Süyûti, A. (1965). Buğyetü'l-vuat fì tabakati'l-lugaviyyin ve'n-nühat. (thk. Muhammed Ebü'l-Fazl İbrâhim). Lübnan: Mektebetü'l-Asriyye.

Süyûti, A. (1967). Hüsnü 'l-muhadara. Muhammed Ebu'l-Fazl İbrahim, Dâru İhyai'l-kütübi'l-arabiyye.

Süyûti, A. (1994). Tabakâtü'l-huffâz. Beyrut: Darü'l-kütübi'l-ilmiyye.

Şevkânî, M. (t.s.). el-Bedrü 't-tali ‘ bi-mehasin men ba 'de'l-karni's-sabi '. Kahire: Darü'l-kitabi'l-İslâmî.

Taceddîn es-Sübkî, A. (1992). Tabakâtü'ş-şafiiyyeti'l-kübrâ. (thk. Mahmûd Muhammed Tanâhi, Abdülfettâh Muhammed el-Hulv). y.y.: Hicr lit'taba'a ve'n-neşr ve't-tevzi'.

Tozlu, İ. (2011). Moğultay b. Kılıç ve hadis ilmindeki yeri. Yayımlanmamış doktora tezi, Selçuk Üniversitesi SBE, Konya.

Tuğlu, N. (1996). Abdullah bin Yusuf ez-Zeyla’i (762/1360) ve Nasbu'r-Raye adlı eserindeki hadisçiliği. Selçuk Üniversitesi SBE, Konya.

Yalçın, M. F. (2016). Bahrî Memlükler döneminde Dımaşk kâdılkudatları. Yayımlanmamış doktora tezi, Marmara Üniversitesi SBE, İstanbul.

Zehebî, M. (1990). Mu'cemü şüyuh. (thk. Ravhiyye Abdurrahman es-Suyûfî). Beyrut: Dârü’l-Kütübü’lİlmiyye. 